\title{
Research on the Value of Rural E-commerce and Rural Surplus Labor Development
}

\author{
Yuwei Wang ${ }^{1}$, Shuhua Nan $^{1}$ \\ ${ }^{1}$ Gongqing College of Nanchang University, Business administration Department, Gongqing, Jiangxi, \\ 332020
}

Keywords: Rural Surplus Labor, Rural E-commerce, Economy Development

\begin{abstract}
China is a big agricultural country. The development of rural economy is a core component of China's modernization process. In recent years, the rapid development of e-commerce has gradually led to the exploration of a new model of rural labor. Based on the analysis of the current situation of e-commerce and the status quo of rural labor economic development in China, this paper analyzes the promotion effect of e-commerce on rural labor economy, and puts forward suggestions for the development of rural e-commerce in China and suggestions for solving the problem of rural surplus labor placement.
\end{abstract}

\section{Introduction}

With the acceleration of China's urbanization speed and the acceleration of rural modernization, especially the major changes in China's rural land system, the biggest problem facing China's rural areas in the future is the transfer and resettlement of surplus labor. How to transfer this part of the labor force from agricultural production to other production sectors and get effective resettlement, so as to achieve the sustainable development of rural surplus labor, is a problem that must be solved and overcome in the development of urbanization and urban-rural integration in China.

\section{The social and institutional background of the rural surplus labor in contemporary China}

China's rural arable land is vast. In the past, it relied on artificial cultivation to consume time, waste resources, and low production efficiency. Modern agricultural technology is characterized by large-scale, high degree of mechanization, various high-tech supporting applications, and relying on agricultural modernization and agricultural labor productivity. Continuous improving. However, the result of high mechanized production is that the demand structure of the labor force will change, the quality requirements for the labor force will continue to increase, and the quantity requirements will continue to decrease, and the quality and quantity will be extremely highly alternative. With the development of agricultural modernization, more rural labor will be separated from land production. Regardless of the form of liberation, the development trend of modern agriculture will generate more rural surplus labor, become an important part of the labor force in the future economic society, and will also challenge the traditional employment structure.

The transfer of rural land contractual management rights is an important innovation in the process of China's agricultural land reform. In the report of the Third Plenary Session of the 18th Central Committee, it was clearly stated that "under the premise of upholding and perfecting the most stringent farmland protection system, granting farmers the possession, use, income, circulation and contractual management rights mortgage and security rights of contracted land”, "establishing urban and rural unification The construction land market. Under the premise of planning and use control, the rural collective construction land is allowed to be transferred, leased, and invested, and the same price as the state-owned land is entered into the market, and the same rights are equal. The scope of land acquisition is reduced, the land acquisition procedures are standardized, and the A reasonable, standardized and diversified guarantee mechanism for land-expropriated farmers. Expand the scope of paid use of state-owned land, reduce the allocation of non-public interest land, establish a land value-added income distribution mechanism that takes into account national, 
collective and individual, and rationally improve personal income. Improve land lease, transfer, mortgage Secondary market". This means that farmers can no longer be confined to their own "one-acre three-point land". Land cultivation is not the only means to maintain a livelihood. Farmers can also do some work within their ability according to their own interests or following social needs. They are no longer passive "landless peasants", but active rural land "operators". At the same time, they can also be liberated from traditional agricultural production and put into social labor in other industrial sectors.

\section{The impact of rural e-commerce on rural surplus labor placement in China}

The resettlement of rural surplus labor in China mainly takes the path of working in cities and local resettlement. Although these two resettlement paths have slowed the employment pressure of rural surplus labor, it is not a long-term solution. On the one hand, working in cities has brought enormous pressure to the social environment, public facilities and transportation. The emergence of "the tide of migrant workers" has caused the loss and cost that can be avoided in China's cities, rural areas and countries. First of all, the town has limited jobs and cannot meet the needs of the rural surplus labor force, and the unemployed people in the town must also participate in the competition, which will put pressure on the life of the laid-off workers of urban residents. Secondly, the migrant workers who work in cities lack the necessary social security. It also increases the difficulty of public security management in cities and towns; thirdly, migrant workers entering the city to work will bring material and spiritual life trauma to left-behind children and left-behind elderly people in rural areas. On the other hand, the path of resettling rural surplus labor will lead to a small and more dispersed layout of township and village enterprises in China, which will hinder the optimization of industrial structure of township enterprises.

The rapid development of rural e-commerce in China has brought new ways for the resettlement of rural surplus labor. Rural e-commerce has different resettlement methods for rural surplus labor and traditional resettlement paths. Rural e-commerce resettlement methods are more diversified and diversified, and different resettlement methods can be adopted for different groups of people. Work placement for rural left-behind women: In rural areas, women have become left-behind women because they need to take care of the elderly and children at home. Rural e-commerce can provide them with suitable jobs, such as warehouse managers or e-commerce in rural e-commerce. Customer service workers, the working hours or workplaces of these jobs are flexible, and increase the income of the family without affecting their normal life. For the placement of farmers who are energetic but lacking in technology: they can work in e-commerce jobs with strong labor, such as logistics, packaging, etc. This kind of job is simple, and only requires the staff to work hard to make this part of the rural surplus. The labor force provides opportunities for work. For the resettlement of people with certain e-commerce technology and e-commerce knowledge: this part of the rural surplus labor can be engaged in the maintenance or technical work of e-commerce, using their professional knowledge to carry out post work. It can be seen that rural e-commerce can carry out hierarchical resettlement according to different levels and crowds of rural surplus labor. Such a resettlement process can comply with the individual will and personal value of the practitioners, and can introduce a large number of e-commerce enterprises in rural areas. labor force. At the same time, it will not bring pressure to the government or society, and to a certain extent, it has greatly accelerated the transfer speed of rural surplus labor from agricultural industry to non-agricultural industry.

\section{Suggestions on the Optimization of Rural Surplus Labor Resettlement Path}

It is very important to choose the e-commerce model according to local conditions. It is necessary to select the appropriate e-commerce model for product sales according to the actual situation of each region. China's e-commerce can be divided into two major categories, one is based on the existing e-commerce group established by the existing industrial clusters, and the other is self-developed, independent production, and self-sales established e-commerce cluster. For regions 
with relatively scarce resources and more surplus labor, they can use favorable external conditions, such as regional industry support and industrial characteristics, to find business opportunities and develop online sales of related industrial products. For areas with special products, we must make good use of them, do not go far, organize local villagers to produce and process special products, make full use of network marketing channels, gradually create their own unique brands, and expand product sales. The choice of e-commerce platform should also be cautious. The advantages and disadvantages of self-built websites and the use of third-party platforms must be carefully weighed according to their own circumstances before making scientific choices.

To develop a staggered economic structure, we must not develop e-commerce because of the good development prospects of e-commerce models. The market cakes will be bigger. Once there are more people, the profits will be thinner. This requires the government to carry out Correct grooming. The government can organize villagers to carry out effective cooperation, clarify the division of labor, and give full play to comparative advantages in order to increase profits. Production and sales must be caught together. For example, villagers who are good at farming or manual production should continue to engage in agricultural production and ensure the demand for agricultural products in the society. Other rural laborers can engage in e-commerce, doing their best and doing their part.

Regional governments that are suitable for e-commerce development should respond positively and make appropriate use of national policies to make correct guidance and support for the development of rural e-commerce, give more preferential policies to the development of local e-commerce, and regularly conduct electronic programs for villagers. Business training to reduce the worries of villagers engaged in e-commerce. The development of rural e-commerce in the eastern region is mostly led by individuals and further developed and expanded through the "acquaintance relationship". The products they produce are highly similar, and the products on the market are nothing new. Some of them pass the price reduction. Competition to grab market share, which reduces revenue and reduces their enthusiasm for online merchants. The government should step in and guide them to diversify the production of products, regulate market order, and avoid vicious competition.

The development of rural e-commerce is from the integration of "agricultural products into the city" to "industrial products to the countryside" and other related industries. In order to create the prosperity of the rural e-commerce ecosystem, a large number of laborers are needed. In the stage of "agricultural products entering the city", the agricultural products farming industry, agricultural product processing industry, other processing industries (such as garment processing, furniture production and other labor-intensive processing industries) are the main development industries, and the supporting commercial service industries, including Business planning, marketing promotion, brand operation, etc. are supplemented, and at the same time, it can cooperate with the development of characteristic agricultural eco-tourism. In the "industrial goods to the countryside" stage, mainly through the online store orders to offline stores experience as a business model, supporting the establishment of various levels of after-sales service stations.

The government started from formulating policies, improving public services, regulating the market, etc., increasing financial support, improving rural public service facilities, encouraging logistics enterprises to sink and arranging rural markets, and e-commerce companies to expand channels and open platforms. Improve the ecological and other work, and at the same time do a good job in local services, product development, and drive farmers. Many parties jointly guided the e-commerce group to do a good job in promotion and operation, new media propaganda, etc., and finally achieved "mass entrepreneurship and innovation." Due to factors such as insufficient profit model and insufficient credit qualifications, rural e-commerce has not been able to obtain bank credits during financing. Government and financial enterprises can provide microfinance services in farmer's agricultural product cultivation and machine plant procurement and construction. The government and related companies should also take the lead in organizing regular training for e-commerce professionals. The implementation of this measure can effectively promote the development of rural e-commerce, but also improve the quality and ability of the rural labor force to 
a certain extent, so that more people can engage in e-commerce. In turn, promote the development of rural labor economy.

\section{Conclusion}

The development of e-commerce not only promotes the release of rural labor, but also allows farmers to engage in e-commerce work, and also drives the demand for labor in the surrounding industries, which further drives the increase in the employment rate of farmers. In addition, the e-commerce sales of agricultural products and the industrialization of rural areas have promoted the benign return of rural labor, enabling large numbers of out-of-town workers to return to the countryside. Therefore, e-commerce plays an important role in promoting the development of rural labor economy.

\section{Acknowledgements}

Fund Project: Jiangxi Provincial Department of Education Science and Technology Research Project 2017 Annual Project: Research on the Development Mechanism of Rural Surplus Labor Force in Jiangxi Province from the Perspective of Rural E-Commerce

Project No.: GJJ171470,

\section{References}

[1] Zhang Dongxing. Discussion on the Effective Ways of Developing Rural Economy to Increase Farmers' Income[J]. Science and Technology Innovation and Application, 2014(7): 247-247.

[2] Zhang Nan. Exploring the potential and expanding the employment space to promote the development of rural labor economy in depth [J]. Jilin Agriculture, 2013 (17): 40-41.

[3] Li Lingfang, Xu Siyuan, Hong Zhanqing. Rural E-commerce: Problems and Countermeasures[J]. Journal of the Party School of Fujian Provincial Committee of the Communist Party of China, 2013(5): 70-74.

[4] Zhuang Erping. Problems and Countermeasures of Rural Labor Export in China[J]. People's Forum, 2013(17): 100-101.

[5] Huang Chao. Research on the Status Quo of Rural E-Commerce Development Demand and Its Constraints [J]. Enterprise Science and Technology and Development, 2014(3):9-11. 